\title{
Evaluation of the new TNM staging system proposed by the International Association for the Study of Lung Cancer at a single institution
}

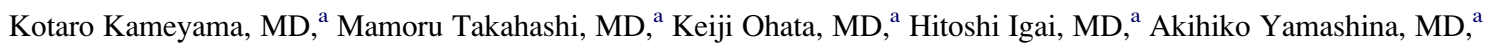

Tomoaki Matsuoka, MD, ${ }^{\mathrm{a}}$ Tatsuo Nakagawa, MD, ${ }^{\mathrm{b}}$ and Norihito Okumura, $\mathrm{MD}^{\mathrm{a}}$

Objective: The seventh TNM Classification of Malignant Tumours will be published in 2009. The International Association for the Study of Lung Cancer has proposed a revision of the current pathologic staging system. We illustrated the effects of this new system and pointed out potential problems using a retrospective study of surgical cases of non-small cell lung cancer at our institution.

\begin{abstract}
Methods: Subjects were 1532 patients for whom current pathologic staging was possible. These data were migrated into the new staging system. The numbers of patients at various stages determined by using the current and new staging systems were, respectively, as follows: IA $(n=700, n=700)$, IB $(n=338, n=249)$, IIA $(n=49$, $\mathrm{n}=164)$, IIB $(\mathrm{n}=129, \mathrm{n}=116)$, IIIA $(\mathrm{n}=204, \mathrm{n}=234)$, IIIB $(\mathrm{n}=77, \mathrm{n}=17)$, and IV $(\mathrm{n}=35, \mathrm{n}=52)$. Prognoses were compared by using the current and the new systems.

Results: By using the new staging system, 5 -year survivals by T classifications were as follows: T1a, $82.6 \%$; T1b, 73.3\%; T2a, 63.5\%; T2b, 50.1\%; T3, 40.6\%; and T4, 34.6\%. There were significant differences between the new T1a and T1b $(P=.0026), \mathrm{T} 1 \mathrm{~b}$ and T2a $(P=.0027)$, and T2a and T2b $(P=.0062)$ classifications. In the current system 5-year survivals based on pathologic stages were as follows: IA, 84.8\%; IB, 72.9\%; IIA, 53.8\%; IIB, 53.7\%; IIIA, 31.8\%; IIIB, 34.0\%; and IV, 27.1\%. There were significant differences between stages IA and IB $(P<.0001)$ and stages IIB and IIIA $(P=.0006)$. In the new system these were as follows: IA, $84.8 \%$; IB, $75.2 \%$; IIA, 62.4\%; IIB, 52.1\%; IIIA, 32.4\%; IIIB, $15.2 \%$; and IV, 30.6\%. There were significant differences between stages IA and IB $(P=.0004)$, IB and IIA $(P=.0195)$, IIA and IIB $(P=.0257)$, IIB and IIIA $(P=$ $.0040)$, and IIIA and IIIB $(P=.0399)$.
\end{abstract}

Conclusion: Although the outcomes for stages IIIB and IV were reversed, the new pathologic staging system was considered valid based on our single-institution evaluation.

Earn CME credits at

http://cme.ctsnetjournals.org

Staging is important for predicting patient prognosis and selecting appropriate treatment for lung cancers. Although the current (sixth edition) TNM Classification of Malignant Tumours by the International Union Against Cancer (UICC) is an excellent staging system, various problems have been indicated for many aspects of lung cancer. ${ }^{1}$ The next edition of the TNM Classification of Malignant Tumours, the seventh, is due to be published in 2009. In preparation for this, the International Association for the Study of Lung Cancer (IASLC) established its Lung Cancer Staging Project in 1998 to formulate recommendations for the seventh edi-

From the Department of Thoracic Surgery, ${ }^{a}$ Kurashiki Central Hospital, Okayama, Japan, and the Department of Thoracic Surgery, ${ }^{b}$ Tenriyorozu Hospital, Nara, Japan. Received for publication June 10, 2008; revisions received Aug 18, 2008; accepted for publication Sept 12, 2008.

Address for reprints: Kotaro Kameyama, MD, Department of Thoracic Surgery, Kurashiki Central Hospital, 1-1-1 Miwa, Kurashiki, Okayama, 710-8602, Japan

(E-mail: kk8724@kchnet.or.jp).

J Thorac Cardiovasc Surg 2009; 137:1180-4

$0022-5223 / \$ 36.00$

Copyright (C) 2009 by The American Association for Thoracic Surgery

doi: $10.1016 /$ j.jtcvs. 2008.09 .030 tion. ${ }^{2,3}$ The project has been recognized by the UICC as the primary source for recommendations for revisions to the sixth edition of the TNM Classification of Malignant Tumours. Lung cancer treatments are based on staging, and changes in staging greatly affect these treatment strategies. For the evaluation of new treatment strategies, there will be a need for the migration of current data into the new staging system in most institutions. We migrated current data for surgical cases of non-small cell lung cancer at our institution into this new system both to illustrate the effects of this new system and to point out potential problems.

\section{MATERIALS AND METHODS}

The subjects were 1532 surgical patients with non-small cell lung cancer at pathologic stages I to IV who were seen at our institution from 1984 to 2007. They underwent resections of tumors with dissection or sampling of lymph nodes, and T, N, and M classifications could be pathologically evaluated. There were 369 patients with squamous cell carcinoma, 1061 with adenocarcinoma, 29 with adenosquamous carcinoma, 35 with large cell carcinoma, and 38 with other types of cancer. The surgical procedures were lobectomy for $1182 \mathrm{pa}-$ tients, bilobectomy for 66 patients, pneumonectomy for 70 patients, completion pneumonectomy for 9 patients, segmentectomy for 130 patients, wedge resection for 74 patients, and 1 other procedure for 1 patient.

The current classification followed the sixth edition of the TNM Classification of Malignant Tumours. ${ }^{1}$ The new classification followed the revised staging system proposed by the IASLC. ${ }^{3}$ In the new TNM classifications, tumors that fulfill the definition for $\mathrm{T} 1$ and are $2 \mathrm{~cm}$ or smaller in the greatest 


\section{Abbreviations and Acronyms \\ IASLC $=$ International Association for the Study of Lung Cancer \\ UICC $=$ International Union Against Cancer}

dimension should be designated T1a, whereas those that are larger than $2 \mathrm{~cm}$ but $3 \mathrm{~cm}$ or smaller in the greatest dimension should be designated T1b. Those tumors that fulfill the present definition of T2 and are $5 \mathrm{~cm}$ or smaller in the greatest dimension become T2a, whereas those that are larger than 5 $\mathrm{cm}$ but $7 \mathrm{~cm}$ or smaller in the greatest dimension become T2b. Tumor dimension of larger than $7 \mathrm{~cm}$ becomes a T3 descriptor. Additional tumor nodules in the lobe of the primary tumor become T3, nodules in other ipsilateral lobes become $\mathrm{T} 4$, and nodules in the contralateral lung remain M1. The presence of malignant pleural effusion, pleural dissemination, or pericardial disease becomes an $\mathrm{M}$ classification. The $\mathrm{M}$ category is subdivided into the following: M1a, which includes the new classifications added to this category (ie, patients with pleural nodules or malignant pleural or pericardial effusion and additional pulmonary nodules in the contralateral lung) and M1b for those patients with other distant metastases. The existing $\mathrm{N}$ classifications were validated, and no changes are proposed. T2a N1 M0 tumors migrate to stage IIA from stage IIB. T2b N0 M0 tumors migrate to stage IIA from stage IB. T4 N0 M0 and T4 N1 M0 tumors migrate to stage IIIA from stage IIIB (Table 1).

Table 2 shows the numbers of patients by $\mathrm{T}, \mathrm{N}$, and $\mathrm{M}$ classifications in the current and new staging systems. The numbers of patients classified by the current and new staging systems were, respectively, as follows: IA ( $\mathrm{n}=$ $700, n=700)$, IB $(n=338, n=249)$, IIA $(n=49, n=164)$, IIB ( $n=129$, $\mathrm{n}=116)$, IIIA $(\mathrm{n}=204, \mathrm{n}=234)$, IIIB $(\mathrm{n}=77, \mathrm{n}=17)$, and IV $(\mathrm{n}=35$, $\mathrm{n}=52$ ). Comparisons of prognoses were performed.

All data were not included in the IASLC database. Computed tomographic analysis of the chest, brain, and upper portion of the abdomen and bone scintigraphic analysis were performed routinely for the preoperative evaluation of the extent of disease. Generally, patients were postoperatively examined at 3-month intervals for 5 years and at 1 -year intervals thereafter to check for recurrence and survival. The median follow-up time was 49 months (range, 0-267 months). Since 1997, induction therapy had routinely preceded the cases for which the preoperative evaluation was greater than stage IIIA. Since 1999, video-assisted thoracoscopic surgery was performed for cases for which the preoperative evaluation was clinical stage I. Since 2002 , adjuvant therapy was used routinely for cases for which the postoperative evaluation was greater than stage IIB. Patients with recurrent disease received chemotherapy, radiotherapy, or both as often as possible. We obtained informed consent from the patients preoperatively for use of clinical data, and our institutional review board approved this retrospective study.

Survival was determined from the date of surgical intervention until death from any cause. Survival curves were calculated by using the Kaplan-Meier method, and differences in survival were evaluated by using a log-rank test. Statistical calculations were done with Stat View 5.0 (SAS Institute, Inc, Cary, NC).

\section{RESULTS}

The 5-year survivals by $\mathrm{T}$ classification in the current staging system were as follows: $\mathrm{T} 1,78.7 \%$; T2, 60.9\%; T3, 34.5\%; and T4, 36.9 (Table 3). The 5-year survivals by $\mathrm{T}$ classifications in the new staging system were as follows: T1, 78.5\%; T2, 60.2\%; T3, 40.6\%; and T4, 34.6\% (Table 4). T4 tended to have a worse prognosis than T3 in the new staging system compared with the current system.
TABLE 1. Classifications, proposed T and M categories, and proposed stage groupings

\begin{tabular}{lccccc}
\hline $\begin{array}{c}\text { Sixth edition T/M } \\
\text { classifications }\end{array}$ & Proposed T/M & N0 & N1 & N2 & N3 \\
\hline $\mathrm{T} 1(\leq 2 \mathrm{~cm})$ & T1a & IA & IIA & IIIA & IIIB \\
T1 $(>2-3 \mathrm{~cm})$ & T1b & IA & IIA & IIIA & IIIB \\
T2 $(\leq 5 \mathrm{~cm})$ & T2a & IB & IIA & IIIA & IIIB \\
T2 $(>5-7 \mathrm{~cm})$ & T2b & IIA & IIB & IIIA & IIIB \\
T2 $(>7 \mathrm{~cm})$ & T3 & IIB & IIIA & IIIA & IIIB \\
T3 invasion & & IIB & IIIA & IIIA & IIIB \\
T4 (same lobe nodules) & & IIB & IIIA & IIIA & IIIB \\
T4 (extension) & T4 & IIIA & IIIA & IIIB & IIIB \\
M1 (ipsilateral lung) & & IIIA & IIIA & IIIB & IIIB \\
T4 (pleural effusion) & M1a & IV & IV & IV & IV \\
M1 (contralateral lung) & & IV & IV & IV & IV \\
M1 (distant) & M1b & IV & IV & IV & IV \\
\hline Entin & &
\end{tabular}

The following are the 5-year survivals by subgroups of $\mathrm{T}$ classifications, which were newly established in the new staging system: T1a, 82.6\%; T1b, 73.3\%; T2a, 63.5\%; and $\mathrm{T} 2 \mathrm{~b}, 50.1 \%$. There were significant differences between the newly established T1a and T1b $(P=.0026)$, T1b and T2a $(P=.0027)$ and T2a and T2b $(P=.0062)$ classifications (Figure 1).

For the $\mathrm{N}$ classifications, the 5-year survivals by the current staging system were as follows: N0, 77.0\%; N1, $54.2 \%$; N2, 28.4\%; and N3, 0.0\%. There were significant differences between N0 and N1 $(P<.0001)$, N1 and N2 $(P<.0001)$ and N2 and N3 $(\mathrm{P}=.0002$, Table 3$)$.

The following are the 5-year survivals by subgroups of $\mathrm{M}$ classifications that were newly established in the new staging system: M0, 68.5\%; M1a, 30.0\%; and M1b, 25.1\%.

TABLE 2. Numbers of patients by $T, N$, and $M$ classifications in the current and new staging systems

\begin{tabular}{lrrrrr}
\hline & N0 & N1 & N2 & N3 & Total \\
\hline Sixth edition T/M & & & & & \\
T1 & 707 & 47 & 73 & 3 & 830 \\
T2 & 345 & 76 & 98 & 6 & 525 \\
T3 & 54 & 21 & 23 & 0 & 98 \\
T4 & 42 & 17 & 18 & 2 & 79 \\
M0 & 1133 & 158 & 198 & 8 & 1497 \\
M1 & 15 & 3 & 14 & 3 & 35 \\
Total & 1148 & 161 & 212 & 11 & 1532 \\
Proposed T/M & & & & & \\
T1a & 440 & 15 & 28 & 3 & 486 \\
T1b & 268 & 32 & 45 & 1 & 346 \\
T2a & 252 & 54 & 70 & 3 & 379 \\
T2b & 80 & 23 & 25 & 2 & 130 \\
T3 & 104 & 31 & 41 & 2 & 178 \\
T4 & 4 & 6 & 3 & 0 & 13 \\
M0 & 1121 & 151 & 200 & 8 & 1480 \\
M1a & 23 & 7 & 7 & 0 & 37 \\
M1b & 4 & 3 & 5 & 3 & 15 \\
Total & 1148 & 161 & 212 & 11 & 1532 \\
\hline
\end{tabular}


TABLE 3. Comparisons of overall survival between TNM classifications by using the sixth edition of TNM classifications

\begin{tabular}{lcccc}
\hline \multicolumn{1}{c}{$\begin{array}{c}\text { Sixth } \\
\text { edition TNM }\end{array}$} & Deaths/no. & $\begin{array}{c}\text { Median } \\
\text { survival (mo) }\end{array}$ & $\begin{array}{c}\text { 5-Year } \\
\text { survival (\%) }\end{array}$ & $\boldsymbol{P}$ value \\
\hline T1 & $120 / 830$ & 53 & 78.7 & - \\
T2 & $166 / 525$ & 46 & 60.9 & $<.0001$ \\
T3 & $58 / 98$ & 35 & 34.5 & $<.0001$ \\
T4 & $38 / 79$ & 33 & 36.9 & .8373 \\
N0 & $192 / 1148$ & 52 & 77.0 & - \\
N1 & $60 / 161$ & 45 & 54.2 & $<.0001$ \\
N2 & $122 / 212$ & 32 & 28.4 & $<.0001$ \\
N3 & $8 / 11$ & 11 & 0.0 & .0002 \\
M0 & $360 / 1497$ & 50 & 68.2 & - \\
M1 & $22 / 35$ & 24 & 27.1 & $<.0001$ \\
Total & $382 / 1532$ & 49 & 67.3 & - \\
\hline
\end{tabular}

$P$ value: Significance value from log-rank test of survival hazard functions relative to preceding row.

There were significant differences between M0 and M1a $(P<.0001)$ and M1a and M1b $(P=.0434$, Table 4$)$.

For the current staging system, the 5 -year survivals by stage were as follows: IA, $84.8 \%$; IB, 72.9\%; IIA, 53.8\%; IIB, 53.7\% $(P=.4951)$; IIIA, $31.8 \%$; IIIB, 34.0\% $(P=$ .7812 ); and IV, $27.1 \%$ (Figure $2, A$ ). There was a significant difference between stages IA and IB $(P<.0001)$ and stages IIB and IIIA $(P=.0006)$. For the new staging system, the 5year survivals by stage were as follows: IA, $84.8 \%$; IB, $75.2 \%$; IIA, $62.4 \%$; IIB, 52.1\%; IIIA, $32.4 \%$; IIIB, $15.2 \%$; and IV, $30.6 \%$. There were significant differences between stages IA and IB $(P=.0004)$, IB and IIA $(P=$ $.0195)$, IIA and IIB $(P=.0257)$, IIB and IIIA $(P=.0040)$, and IIIA and IIIB $(P=.0399)$; (Figure $2, B)$.

\section{DISCUSSION}

Although the current (sixth edition) TNM Classification of Malignant Tumours by the UICC is an excellent staging system, various problems have been indicated in many aspects for lung cancer. ${ }^{1,4,5}$ The next edition of the TNM Classification of Malignant Tumours, the seventh, is due to be published in 2009. In preparation for this, the IASLC estab-

TABLE 4. Comparisons of overall survival between $T$ and $M$ classifications by using the new TNM classifications proposed by the International Association for the Study of Lung Cancer

\begin{tabular}{lcccc}
\hline $\begin{array}{c}\text { Proposed } \\
\text { TM }\end{array}$ & Deaths/no. & $\begin{array}{c}\text { Median } \\
\text { survival (mo) }\end{array}$ & $\begin{array}{c}\text { 5-Year } \\
\text { survival (\%) }\end{array}$ & $\begin{array}{c}\boldsymbol{P} \\
\text { value }\end{array}$ \\
\hline T1 & $122 / 832$ & 53 & 78.5 & - \\
T2 & $162 / 509$ & 46 & 60.2 & $<.0001$ \\
T3 & $90 / 178$ & 37 & 40.6 & $<.0001$ \\
T4 & $8 / 13$ & 21 & 34.6 & .3343 \\
M0 & $354 / 1480$ & 50 & 68.5 & - \\
M1a & $18 / 37$ & 34 & 30.0 & $<.0001$ \\
M1b & $10 / 15$ & 10 & 25.1 & .0434 \\
Total & $382 / 1532$ & 49 & 67.3 & - \\
\hline
\end{tabular}

$P$ value: significance value from log-rank test of survival hazard functions relative to preceding row.

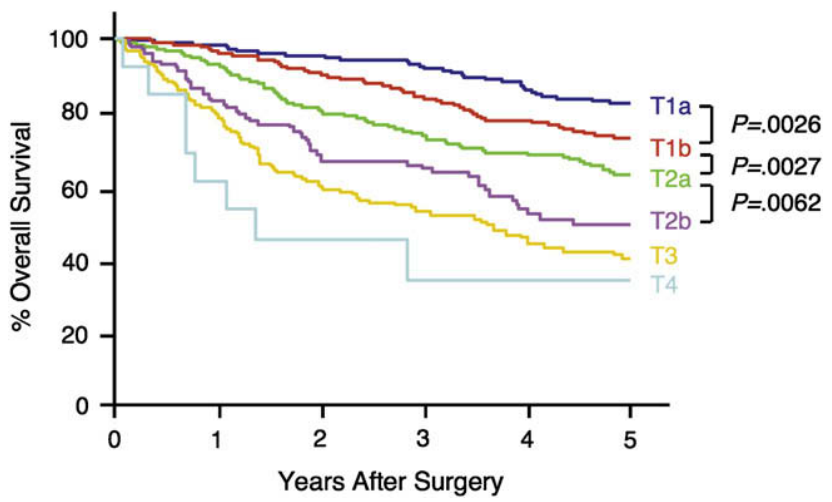

FIGURE 1. Overall survival based on pathologic T classification subgroups proposed by the International Association for the Study of Lung Cancer. There were significant differences between the newly established T1a and T1b $(P=.0026)$, T1b and T2a $(P=.0027)$, and T2a and T2b $(P=.0062)$ classification.

lished its Lung Cancer Staging Project in 1998 to bring together the large databases available worldwide and to formulate recommendations for the seventh edition that would be intensively validated. ${ }^{2,3}$ Analysis of data from 81,015 cases worldwide was performed. The IASLC proposed a revision of the current staging system that was presented at the 12th World Conference on Lung Cancer. In addition, the details were published in the Journal of Thoracic Oncology. ${ }^{3,6-9}$ The new staging system was based on an intensive and validated analysis of the largest database available to date. It is highly likely that the next edition of the TNM Classification of Malignant Tumours will be based on this new staging system.

In our analyses of prognoses by the $\mathrm{T}$ classifications, there were clear differences between T1a and T1b, between T1b and T2a, and between T2a and T2b, which were new subgroups in the new staging system. It has been previously shown that there are clear differences in prognosis based on tumor size. ${ }^{10-12}$ In the new staging system optimal cut points for tumor size were determined by using "a running log-rank test." Indications for limited operations and the significance of postoperative adjuvant therapy for $\mathrm{T} 1$ and T2 cases have been discussed. ${ }^{13-16}$ Furthermore, the detailed studies of subgroupings in the new staging system are more useful. In the new staging system, compared with the current system, T3 tended to show a better prognosis than T4. This resulted as ipsilateral pulmonary nodules in the same lobe were changed from T4 to T3 and ipsilateral pulmonary nodules in another lobe were changed from M1 to T4. The prognoses for these groups were previously considered to be good based on the current classification system, and these changes were considered valid. ${ }^{17,18}$ In the analyses for prognoses by the $\mathrm{M}$ classifications, there were differences in prognosis among M1a, M1b, and M0, which were established in the new staging system. ${ }^{8}$ In the analyses for prognoses by stages, there were differences in prognosis between 

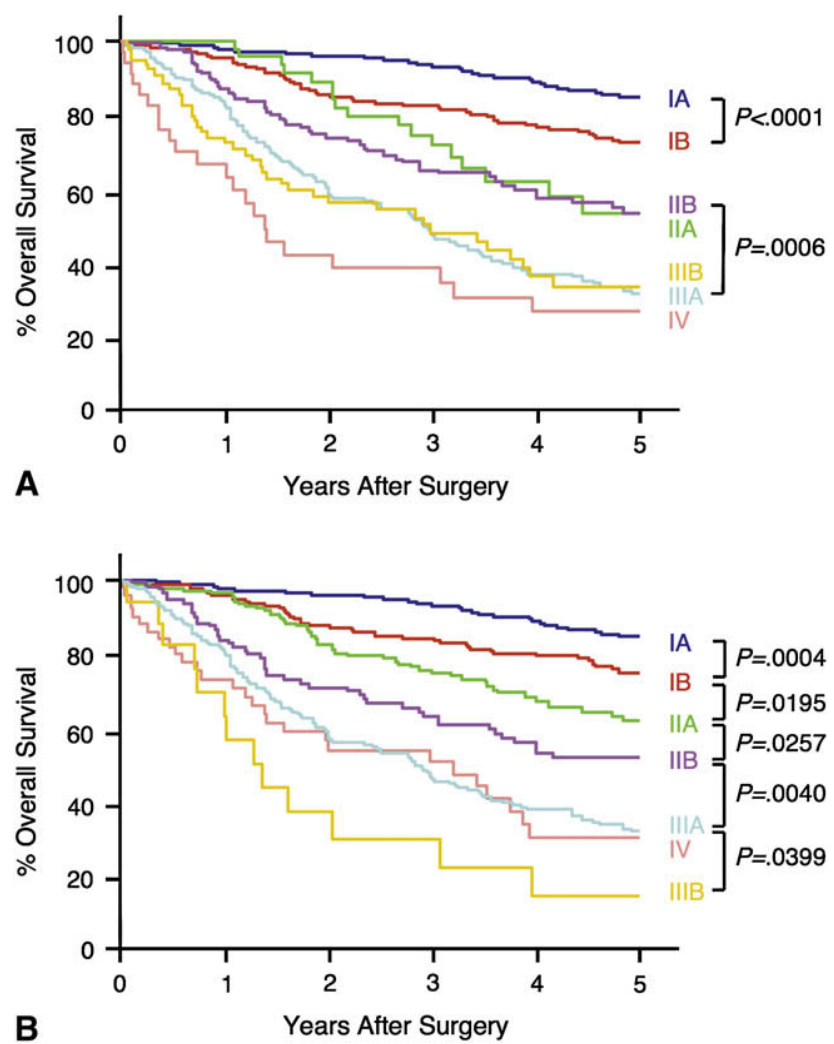

FIGURE 2. Overall survival based on pathologic stage. Survival based on the sixth edition of the TNM classifications (A) and the new TNM classifications proposed by the International Association for the Study of Lung Cancer (B) is shown. The numbers of patients classified by the current and new staging systems were as follows: IA $(n=700, n=700)$, IB ( $\mathrm{n}=338, \mathrm{n}=249)$, IIA $(\mathrm{n}=49, \mathrm{n}=164)$, IIB $(\mathrm{n}=129, \mathrm{n}=116)$, IIIA $(\mathrm{n}=204, \mathrm{n}=234)$, IIIB $(\mathrm{n}=77, \mathrm{n}=17)$, and IV $(\mathrm{n}=35, \mathrm{n}=52)$. In the current system there were significant differences between stages IA and IB $(P<.0001)$ and between stages IIB and IIIA $(P=.0006)$. In the new staging system there were significant differences between IA and IB $(P=.0004), \mathrm{IB}$ and IIA $(P=.0195), \mathrm{IIA}$ and IIB $(P=.0257)$, IIB and IIIA $(P=.0040)$, and IIIA and IIIB $(P=.0399)$.

stages IIA and IIB and between stages IIIA and IIIB in the new staging system. These differences were not seen in the current staging system.

A problem with the new staging system is the reversal of outcomes for stages IIIB and IV. These trends were also seen for pathologic staging in the new IASLC staging system. ${ }^{3,9}$ However, the reason for the reversal was not described. For the operative cases, the numbers of pathologic stage IIIB and IV tumors are too small for evaluation. However, the patients with a good prognosis might be included in stage IV, especially M1a. In fact, for our patients, there were significant differences between M1a and M1b. Contralateral pulmonary nodules, which are detected by means of imaging and not proved pathologically, might not be metastatic. ${ }^{17} \mathrm{~Pa}-$ tients with malignant effusion (dissemination) and no distant metastases might be offered a good prognosis with an oper- ation and adjuvant therapy. ${ }^{19-22}$ Therefore the M1a classification might have to be reconsidered.

For pathologic staging proposed by the IASLC, the revisions that focused on the T classifications were reflected well by the improvements for stages I to III. Although the outcomes for stages IIIB and IV were reversed, the new pathologic staging system was considered valid based on our single-institution evaluation.

\section{References}

1. Sobin L, Wittekind C. International Union Against Cancer (UICC): TNM classification of malignant tumours. 6th ed. New York: John Wiley \& Sons; 2002.

2. Goldstraw P, Crowley J. The International Association for the Study of Lung Cancer International Staging Project on Lung Cancer. J Thorac Oncol. 2006;1:281-6.

3. Goldstraw P, Crowley J, Chansky K, Giroux DJ, Groome PA, Rami-Porta R, et al. The IASLC Lung Cancer Staging Project: proposals for the revision of the TNM stage groupings in the forthcoming (seventh) edition of the TNM Classification of malignant tumours. J Thorac Oncol. 2007;2:706-14.

4. Sobin L, Wittekind C. International Union Against Cancer (UICC): TNM classification of malignant tumours. 5th ed. New York: John Wiley \& Sons; 1997.

5. Mountain CF. Revisions in the International System for Staging Lung Cancer. Chest. 1997;111:1710-7.

6. Rami-Porta R, Ball D, Crowley J, Giroux DJ, Jett J, Travis WD, et al. The IASLC Lung Cancer Staging Project: proposals for the revision of the T descriptors in the forthcoming (seventh) edition of the TNM classification for lung cancer. J Thorac Oncol. 2007;2:593-602.

7. Rusch VW, Crowley J, Giroux DJ, Goldstraw P, Im JG, Tsuboi M, et al. The IASLC Lung Cancer Staging Project: proposals for the revision of the $\mathrm{N}$ descriptors in the forthcoming seventh edition of the TNM classification for lung cancer. J Thorac Oncol. 2007;2:603-12.

8. Postmus PE, Brambilla E, Chansky K, Crowley J, Goldstraw P, Patz EF Jr, et al. The IASLC Lung Cancer Staging Project: proposals for revision of the M descriptors in the forthcoming (seventh) edition of the TNM classification of lung cancer J Thorac Oncol. 2007;2:686-93.

9. Groome PA, Bolejack V, Crowley JJ, Kennedy C, Krasnik M, Sobin LH, et al. The IASLC Lung Cancer Staging Project: validation of the proposals for revision of the $\mathrm{T}, \mathrm{N}$, and $\mathrm{M}$ descriptors and consequent stage groupings in the forthcoming (seventh) edition of the TNM classification of malignant tumours J Thorac Oncol. 2007;2:694-705.

10. Martini N, Bains MS, Burt ME, Zakowski MF, McCormack P, Rusch VW, et al Incidence of local recurrence and second primary tumors in resected stage I lung cancer. J Thorac Cardiovasc Surg. 1995;109:120-9.

11. Inoue K, Sato M, Fujimura S, Sakurada A, Takahashi S, Usuda K, et al. Prognostic assessment of 1310 patients with non-small-cell lung cancer who underwent complete resection from 1980 to 1993. J Thorac Cardiovasc Surg. 1998;116:407-11.

12. Gajra A, Newman N, Gamble GP, Abraham NZ, Kohman LJ, Graziano SL. Impact of tumor size on survival in stage IA non-small cell lung cancer: a case for subdividing stage IA disease. Lung Cancer. 2003;42:51-7.

13. Ginsberg RJ, Rubinstein LV. Randomized trial of lobectomy versus limited resection for T1 N0 non-small cell lung cancer. Lung Cancer Study Group. Ann Thorac Surg. 1995;60:615-23.

14. Kodama K, Doi O, Higashiyama M, Yokouchi H. Intentional limited resection for selected patients with T1 N0 M0 non-small-cell lung cancer: a single-institution study. J Thorac Cardiovasc Surg. 1997;114:347-53.

15. Arriagada R, Bergman B, Dunant A, Le Chevalier T, Pignon JP, Vansteenkiste J. Cisplatin-based adjuvant chemotherapy in patients with completely resected nonsmall-cell lung cancer. $N$ Engl J Med. 2004;350:351-60.

16. Kato H, Ichinose Y, Ohta M, Hata E, Tsubota N, Tada H, et al. A random ized trial of adjuvant chemotherapy with uracil-tegafur for adenocarcinoma of the lung. $N$ Engl J Med. 2004;350:1713-21.

17. Kameyama K, Huang CL, Liu D, Okamoto T, Hayashi E, Yamamoto Y, et al. Problems related to TNM staging: patients with stage III non-small cell lung cancer. J Thorac Cardiovasc Surg. 2002;124:503-10.

18. Aokage K, Ishii G, Nagai K, Kawai O, Naito Y, Hasebe T, et al. Intrapulmonary metastasis in resected pathologic stage IIIB non-small cell lung cancer: possible contribution of aerogenous metastasis to the favorable outcome. J Thorac Cardiovasc Surg. 2007;134:386-91. 
19. Ichinose Y, Tsuchiya R, Koike T, Kuwahara O, Nakagawa K, Yamato Y, et al. The prognosis of patients with non-small cell lung cancer found to have carcinomatous pleuritis at thoracotomy. Surg Today. 2000;30:1062-6.

20. Ohta Y, Tanaka Y, Hara T, Oda M, Watanabe S, Shimizu J, et al. The clinicopathological and biological assessment of lung cancers with pleural dissemination. Ann Thorac Surg. 2000;69:1025-9.
21. Manac'h D, Riquet M, Medioni J, Le Pimpec-Barthes F, Dujon A, Danel C. Visceral pleura invasion by non-small cell lung cancer: an underrated bad prognostic factor. Ann Thorac Surg. 2001;71:1088-93.

22. Reyes L, Parvez Z, Regal AM, Takita H. Neoadjuvant chemotherapy and operations in the treatment of lung cancer with pleural effusion. $J$ Thorac Cardiovasc Surg. 1991;101:946-7.

Access to The Journal of Thoracic and Cardiovascular Surgery Online is reserved for print subscribers!

Full-text access to The Journal of Thoracic and Cardiovascular Surgery Online is available for all print subscribers. To activate your individual online subscription, please visit The Journal of Thoracic and Cardiovascular Surgery Online, point your browser to http://www.mosby.com/itcvs, follow the prompts to activate your online access, and follow the instructions. To activate your account, you will need your subscriber account number, which you can find on your mailing label (note: the number of digits in your subscriber account number varies from 6 to 10). See the example below in which the subscriber account number has been circled:

\section{Sample mailing label}

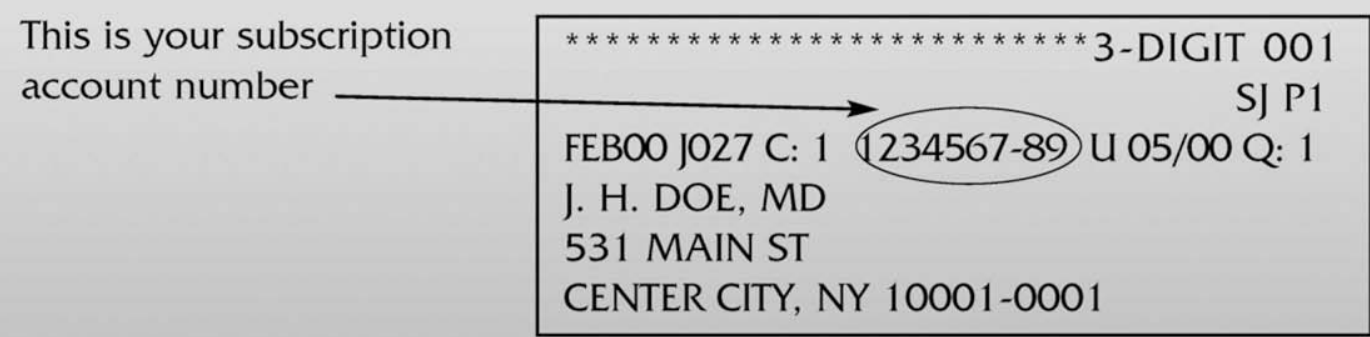

Personal subscriptions to The Journal of Thoracic and Cardiovascular Surgery Online are for individual use only and may not be transferred. Use of The Journal of Thoracic and Cardiovascular Surgery Online is subject to agreement to the terms and conditions as indicated online. 